\title{
A história encenada em Os Sertões de Euclides da Cunha
}

\author{
Berthold Zilly
}

que faz de Os Sertôes uma obra de arte? O que faz de Os Sertões, Os Sertōes? Seu valor científico, historiográfico, literário? $\mathrm{O}$ conteúdo ou a forma, a postura ética ou o estilo imponente? Se o livro de Euclides entrou nos cânones da literatura nacional e universal, isto se deve relativamente pouco a seu valor documental ou historiográfico no sentido acadêmico, já que o autor passou menos de três semanas no campo de batalha, o que é pouco para uma guerra que durou onze meses e que teve antecedentes de décadas, senão de séculos. Além disso, Euclides deu às fontes um tratamento pouco apropriado, menos de historiador do que de jornalista, quando muito de ensaísta, tendo sido leviano ou mesmo irresponsável algumas vezes, se pensarmos naquilo que afirma sobre as prédicas do Conselheiro, as quais comenta, obviamente sem tê-las lido, como se seguisse o lema tácito de certos críticos literários: "Não li, não gostei" ${ }^{1}$. Quase todas as informa- ções factuais e muitas das avaliaçōes e reflexões contidas em Os Sertōes encontram-se também em outros autores, de modo que, sem exagerar, podemos afirmar que, se o livro de Euclides não existisse, saberíamos o mesmo que sabemos hoje sobre a guerra de Canudos, não perdendo praticamente nada a respeito dos fatos e muito pouco a respeito das hipóteses e conclusões, algumas das quais nos são, hoje em dia, inteiramente datadas e dispensáveis, como, por exemplo, as idéias sobre as correspondências entre raça e civilização. Como se explica, pois, o extraordinário êxito do livro de Euclides junto ao público letrado, à opinião pública em geral, aos críticos literários e aos próprios historiadores, que durante décadas deixaram de empreender pesquisas de maior vulto sobre Canudos, já que Euclides haveria escrito o livro definitivo sobre o assunto? Talvez uma das razões desse sucesso seja justamente o caráter abrangente do livro, seu caráter de summa, e ao mesmo tempo sua

Berthold Zilly é professor da Universidade de Berlim e tradutor de Os Sertōes para o alemão.

* Este artigo foi elaborado a partir da palestra "Metáforas pictóricas e teatrais em Os Sertōes", proferida na Casa das Culturas do Mundo (Haus der Kulturen der Welt), em Berlim, em julho de 1995, por ocasião de um simpósio intitulado História como encenação, o caso de 'Os Sertōes' de Euclides da Cunha.

1 Euclides comenta fontes que não leu, utiliza-se de fontes sem crédito, reproduz boatos, transcreve diários de soldados que deixa no anonimato, não fazendo nenhum esforço para preservar algumas das fontes das quais lança mão, como esses diários, cartas de jagunços ou as prédicas do Conselheiro. Tem mais zelo documental quando se trata de reproduzir poesia popular, fontes marginais para um historiador profissional. Sobre a relação de Euclides da Cunha com suas fontes, ver Bernucci, 1995. 
indefinição, ou melhor, sua multiplicidade de gêneros, essa capacidade de reunir quase todas as informações, atitudes, formas possíveis de outros enunciados - relatos, poemas, pichaçóes, artigos e livros sobre a guerra - e ainda aspectos de vários tipos de texto: crônica, lenda, depoimento, diário, tratado geográfico, etnográfico e historiográfico, registro de formas simples populares (Jolles, 1976), mas também romance, ensaio, discurso forense e político, oração fúnebre, tudo amalgamado num estilo relativamente coeso, próprio, inconfundível. Por conseguinte, quanto às três formas básicas da literatura - a epopéia, o drama, a lírica -, o livro reúne todas, como muitos críticos têm apontado, enfatizando principalmente os traços de epopéia e tragédia nele contidos, sendo a versificação embutida em Os Sertôes objeto de estudo recente de Augusto de Campos (1997). É um livro-síntese, reunindo diversos gêneros, temas, pontos de vista, métodos de pesquisa e ideologias. Síntese quase enciclopédica, mas de sistematização duvidosa, incoerente, polissêmica, sugestiva, ativando a imaginação do leitor. $\mathrm{O}$ autor expóe com a maior clareza sua própria falta de clareza, radicaliza suas hesitações e contradições, exacerba os paradoxos. São muitos livros num só.

\section{Entre a ciência e a literatura}

A história de um lugar, de um período curto e de um personagem dominador é mais concreta, mais palpável, mais sugestiva do que a de uma série de acontecimentos disseminados entre regiōes, períodos e líderes diversos. Essa concentração nos planos do espaço, do tempo e do pessoal faltou à maioria dos conflitos comparáveis. Deste modo, a própria realidade vem de encontro à sua literaturização e, principalmente, à sua teatralização. Pois fica evidente que a guerra de Canudos preenche, aproximativamente, vários requisitos do drama clássico: as unidades do lugar, do tempo, do enredo, principalmente se abstraímos da forma rigorosa dessas unidades que foi mais uma invenção do classi- cismo francês do que um requisito da poética aristotélica. A unidade do tempo talvez seja menos patente no caso da guerra de Canudos, pois evidentemente durou mais de um dia, mas mesmo assim no plano cronológico o evento presta-se a ser lembrado intensamente, pois ocupa menos de um ano, bem menos do que a guerra do Paraguai ou a guerra do Contestado. Os onze meses da guerra no sertão são marcados, fora longos períodos de trégua ou de guerra de trincheiras relativamente imóvel, por alguns poucos clímax incisivos, em que as diversas expediçôes e, no caso da quarta, as diversas subexpedições, se concentram, com desfechos curtos, de suspense, dramáticos. Essa constância, pelo menos relativa, do lugar e do tempo ajuda a memória coletiva, ajuda a imaginação, ajuda tanto a narrativa reflexiva do historiador como a narrativa evocadora do escritor.

Se a unidade é óbvia no plano do enredo, ou seja, da guerra, ela o é bem menos no plano dos personagens. Embora pouco visível para os observadores de fora, paira sobre toda a guerra a figura do Conselheiro, reforçando prática e simbolicamente a unidade do povo de Canudos, mesmo porque esse líder espiritual e profano é uma espécie de encarnação do sertanejo como tipo social, como coletividade, que na verdade é o principal sujeito, o protagonista dos acontecimentos. Se o líder camponês é uma presença contínua durante a guerra toda, o exército, por outro lado, não se encarna do mesmo jeito em uma pessoa, tendo cada nova expedição um novo comandante - ficando a quarta expedição, constituída na verdade por várias expediçôes, com vários comandantes, e na última fase com o ministro da guerra perto do campo de batalha, como eminência parda. De modo que há uma certa assimetria entre o pessoal dos dois partidos beligerantes, pois a coesão e continuidade dos canudenses, personificada no Conselheiro, não têm a contrapartida de uma tropa única, com comando único através das quatro campanhas.

Euclides da Cunha, por sua vez, oscila entre dois modos de ver a realidade: um, analítico; 
outro, impressionista, sem que sejam excludentes, embora haja uma tensão entre eles. Muitas vezes estes dois modos complementam-se de maneira feliz, a fim de formar uma seqüência ou até uma simbiose expressiva e sugestiva, como, por exemplo, num trecho do item III, "Higrômetros Singulares", dentro do capítulo "O Homem", que lembra um poema de Rimbaud: Le Dormeur du Val (O Adormecido do Vale). Várias vezes, como também no caso citado, esses dois modos de ver se relacionam como seqüência de ilusão-desilusão. $\mathrm{O}$ olhar ingênuo se deixa iludir à primeira vista, é corrigido por uma segunda visão ou pela ciência, que por sua vez é auxiliada pelo olhar desprevenido do viandante, dotado porém de sensibilidade artística. Pois a ciência pode fracassar ou errar, induzindo o observador a enganos ou se mostrando simplesmente inoperante. É quase um fio condutor do livro a idéia de que o sertão e, muito especialmente, o sertão de Canudos, bem como a guerra aí ocorrida, fogem aos padrōes científicos e se mostram, devido a suas contradições, impenetráveis e imperscrutáveis ao discernimento racional, não cabendo, portanto, nas categorias de pensadores como Hegel ou Humboldt. Esta insuficiência da abordagem científica exigiria uma complementação pelas artes.

Para dar conta dessa realidade que não se deixa equacionar cientificamente, e ao mesmo tempo para fazer jus ao seu caráter enigmático e paradoxal, avesso às interpretações racionais e coerentes, o autor lança mão de métodos e recursos não científicos, almejando o ideal do consórcio da ciência e da arte. ${ }^{2}$ Não uma ficção científica, naturalmente, mas uma ficção histórica, com alternância entre ciência literaturizada e literatura com rigor científico. Entenda-se por ciência toda procura, combinação e apresentação sistemática e metódica de conhecimentos, inclusive nas ciências sociais. A literaturização abandona ou atenua a sistematização, o rigor metodológico, a verificabilidade, para dar vazão à subjetividade e à fantasia, ambas contidas e controladas, porém, pela busca ansiosa, quase fanática da verdade. Parece impossível servir com a mesma fidelidade às duas amas, à ciência e à literatura, consideradas as diferenças entre as duas quanto a meios e fins, criando a necessidade de se dar prioridade, senão exclusividade, a uma delas. E para Euclides da Cunha a opção pela literatura é clara, embora não sem hesitações - quer dizer, talvez seja mais clara para nós do que para ele mesmo. Ainda que não fale de literatura como programa na Nota Preliminar, onde expõe suas metas de historiador científico, aproxima-se dela na fórmula do narrador sincero, do observador empático e quase participante da história, segundo o lema de Taine: "Il veut sentir en barbare, parmi les barbares, et, parmi les anciens, en ancien". E decidese pelo ensaio poética e retoricamente elaborado, belo, sublime, mas também apelativo, amargo, sarcástico ou emocionante, encenando, sim, a história, mas sempre de modo controlado, como "fantasia exata". Para atingir a sugestividade almejada, o autor, ao se servir de recursos literários, faz também empréstimos a outras artes, principalmente à pintura e ao teatro, evocados através da linguagem, criando quase uma espécie de Gesamtkunstwerk, uma obra de arte totalizadora, intermedial, intersemiótica, embora construída com palavras escritas apenas, dentro da literatura cientifizada ou ciência literaturizada. Em vez de escrever e narrar objetivamente situações e eventos, ele o faz como se falasse

2 Carta a José Veríssimo (Galvão; Galotti, 1997, p. 143). Na mesma carta, escreve Euclides: "Eu estou convencido que a verdadeira impressão artística exige, fundamentalmente, a noção científica do caso que a desperta - e que, nesse caso, a comedida intervenção de uma tecnografia própria se impõe obrigatoriamente - e é justo desde que se não exagere ao ponto de dar um aspecto de compêndio ao livro que se escreve, mesmo porque em tal caso a feição sintética desapareceria e com ela a obra de arte." (Ibid., p. 144). 
de obras plásticas ou obras cênicas, representando essas situações e eventos. Euclides encena conscientemente a história. A tarefa do historiador poético é menos a pesquisa de detalhes factuais e sua conexão causal, como seria de se esperar de um pensador positivista, do que a reconstrução de situações e peripécias decisivas ou típicas, memoráveis e elucidativas. $\mathrm{O}$ autor recorta a seqüência dos acontecimentos em quadros e cenas, descritas com intensa plasticidade e poder de presentificação, sustendo volta e meia o decorrer do tempo, parando a fugacidade dos momentos para melhor fixá-los, evidenciando tão bem a simultaneidade dos fatos quanto sua sucessão, o que explica o uso freqüente, ao lado do pretérito perfeito, do imperfeito, surpreendente num relato rico em eventos sucessivos e dramáticos, e do presente histórico, inusitado num relato histórico-científico, avivando, agilizando muitas vezes esses quadros estáticos, transformando-os em cenas dramáticas. Ou seja, ele usa técnicas narrativas ora pictóricas, ora teatrais, como se conduzisse o leitor por uma exposição de desenhos, pinturas e esculturas que de repente começassem a se mover, transformando-se em episódios de um drama ou cenas de um filme a desenrolar-se diante de nossos olhos. Assim, o texto, ora mais descritivo, ora mais narrativo, nos põe diante de uma seqüência de imagens caracterizadas por processos alternantes de aceleração e desaceleração.

Para suprimir todas as dúvidas sobre as intençôes pictórico-teatrais de seu texto, Euclides usa e abusa de metáforas pertencentes às artes plásticas, não sendo menos numerosas aquelas de origem teatral. É claro que muitas dessas metáforas, sendo de uso corrente, encontramse um pouco gastas e empalidecidas, mas sua extraordinária cumulação evidencia a preocupação pictórica e encenatória do autor, sua intenção de visualizar e, em menor grau, sonorizar os fatos relatados em seus estados de mobilidade e imobilidade, embora o faça em vários trechos também sem a utilização dessas metáforas.

Euclides apela do mesmo modo às ciências para evidenciar e presentificar o narrado: a medicina, a geologia, a matemática. No entanto, a literatura continua a fornecer o material principal para caracterizar a história e o mundo, através da velha metáfora do livro, juntamente com outras metáforas a ele ligadas, como, por exemplo, página, palimpsesto, libelo, cronista, lenda, romancear. A realidade se presta não só para ser pintada ou encenada; de certa forma ela já é quadro, já é teatro e também literatura, restando ao observador ativo apenas a tarefa de registrar em palavras aquilo que lê e vê, essas imagens, essas cenas, essas páginas da História, desempenhando o papel de copista, de cronista, de testemunha, de narrador sincero. A meio caminho entre a pintura e a literatura narrativa, a teatralidade como tipo de apresentação da História exerce um papel central entre a imagem e o relato de eventos, entre a pura visualização e o discurso explicativo. Ao mesmo tempo, o teatro trabalha com a expressão acústica e, eventualmente, até com a olfática, sendo uma das artes mais abrangentes e sensoriais, impressionando todos os sentidos da percepção humana. Não é por acaso que, apesar de seu pendor cientificista, Euclides foi tachado aqui e ali de barroquizante, dada a grande predileção do barroco pela teatralidade. Ele pára, sustém e fixa o fluxo da história, dividindo-a e subdividindo-a em situações apresentadas como quadros ou cenas que se movem. Os quadros mais ou menos estáticos predominam naturalmente nas duas primeiras partes, mais descritivas, "A Terra" e "O Homem", enquanto que a partir de "A Luta", quando a dramaticidade se intensifica, predominam as cenas. Porém os quadros são sempre dramáticos, enquanto as cenas, até o final do livro, têm sempre algo de pictórico ou estatuário, produzindo oximoros que resultam da simultaneidade de paralisação e dinamismo.

Parece contraditório falar de tendências pictóricas e teatrais ao mesmo tempo, já que a pintura significa estagnação e o drama, movimento. No entanto, a epopéia reúne as duas tendências, intercalando na narração de eventos sucessivos longas descrições de quadros e imagens, como ocorre freqüentemente na Ilíada, 
por exemplo, na famosa descrição do escudo de Aquiles. Em Euclides, porém, já o dissemos, o movimento é flagrado em quadro imóvel, mas de uma imobilidade tensa, dinâmica, prestes a desatar-se, quase explosiva, como, por exemplo, na descrição dos quadros da natureza morta. Os pequenos quadros e os grandes painéis, às vezes panorâmicos, aspiram a mover-se, e as cenas de intensa movimentação são flagrantes, chapas batidas em peripécias, de modo que a arte dramática se torna pictórica e a arte plástica, dramática. Os quadros são cheios de ações, colisões, conflitos contidos prestes a estourar, graças ao estilo tenso, contorcido, algo expressionista. Enriquecida de elementos pictóricos, essa teatralidade não é a mesma da peça de teatro, mas uma teatralidade desenvolvida pela magia da palavra e reforçada por uma oratória ora contemplativa, ora inflamada, ora objetiva, que evoca todas as cenas na mente do leitor, transformado tanto em espectador quanto em encenador, já que é levado a imaginar plasticamente as sugestões do texto. $\mathrm{O}$ evocador desse teatro é ao mesmo tempo historiador com atitude de professor, poeta, advogado e acusador perante o tribunal da Civilização e da Posteridade. Em última análise, essa retórica evocadora de quadros e cenas teatrais visa a captar e emocionar o público, constituído dos letrados do Brasil e do mundo. Sentado por assim dizer num vasto anfiteatro ao redor do autor, este público escuta com atenção aquele que declama em voz alta o texto do livro. A arte está aí a serviço da verdade histórica e esta, a serviço da ética política: construção de uma nação civilizada, com direito à vida e à cidadania para todos, e condenação, pelo menos moral, dos assassinos e seus cúmplices, inclusive a indústria bélica européia.

\section{Um drama em cinco atos}

Olhemos a composição do livro em sua macroestrutura. É interessante observar que na edição Aguilar, organizada por Afrânio Coutinho em 1966 e reeditada em 1995, sejam apresentadas as personagens do livro como dramatis personae, ou seja, como personagens de um drama, embora elas fossem pessoas reais (ver Cunha, 1966, v. 2, p. 77-87; ver também Coutinho, 1995, p. 57-62). E realmente, o livro é construído de certo modo como um drama em cinco atos, que se configuram assim: ${ }^{3}$

A Terra, O Homem, A Luta: I ato;

Travessia do Cambaio: II ato;

Expedição Moreira César: III ato;

Quarta Expedição: IV ato;

Nova fase da luta; Últimos dias: $\mathrm{V}$ ato.

Ou seja, o primeiro ato seria a exposição do teatro da guerra, metáfora corriqueira na época, dos personagens, dos possíveis motivos do conflito e seu início em Uauá, terminando com a frase significativa, profética: "Estava pronto o cenário para um emocionante drama da nossa história" (Cunha, 1966, p. 284) ${ }^{4}$. Na primeira parte deste ato, a própria terra prepara o palco para os homens, os índios, os bandeirantes, os jesuítas, os vaqueiros, os canudenses e os soldados. A terra e seus deuses também intervêm na ação, ajudando os sertanejos, como fizeram oferecendo-lhes montanhas que funcionam como fortalezas e bastiōes. A história natural funciona assim como cenógrafo, ao passo que a história humana exerce o papel de diretor de teatro, havendo uma ligação entre os dois. As viagens que o narrador faz, principalmente em "A Terra”, produzem uma série de quadros e cenas que ele contempla, preferencialmente, a partir de

3 Karsten Garscha, professor de literaturas românicas na Universidade de Frankfurt am Main, chama o livro de "tragédia em 5 atos, quatro expedições e a fase final da luta" (Garscha, 1994).

4 Todas as citações de Os Sertôes referem-se à edição de 1966. 
duas tribunas elevadas, dois miradouros, que ajudam a organizar o espaço: o alto da serra de Monte Santo e o morro da Favela. Na apresentação do principal protagonista humano, o sertanejo, o autor dificulta seu próprio trabalho, apresentando-o como pouco teatral ao compará-lo com o gaúcho, este, sim, vistoso, garboso, dramático. O livro realiza, portanto, a teatralização de um tipo não teatral. No fundo, a guerra nada tem de grandioso, sublime ou heróico; apesar disso, é encenada como uma grande tragédia. E o não-herói, o sertanejo, vai-se revelando como o único herói.

O segundo ato apresenta, com crescente tensão dramática, a primeira batalha séria, iniciada pela expedição Febrônio de Brito. É uma pequena peça de teatro em si, como todos os atos dessa tragédia que é o livro como um todo, terminando desta vez em farsa: os lutadores embaixo seguiam como atores infelizes no epílogo de um drama mal representado. Toda a agitação de dois dias sucessivos de combates e provações tinha o repentino desfecho de uma arruaça sinistra (p. 312). É interessante observar que Euclides atribui de vez em quando aos próprios partidos beligerantes intenções teatrais, um comportamento de espectadores ou até de encenadores. Assim, nos primeiros atos os sertanejos vaiam os soldados, ao passo que no último os soldados é que vaiam os sertanejos. No fim do epílogo deste segundo ato são mostrados apenas os sertanejos, carregando seus mortos para casa.

O terceiro ato já apresenta uma primeira grande peripécia: a catástrofe da expedição Moreira César, que também se desenrola ela mesma como um drama, com exposição, colisões, retardamentos, subperipécias e um desenlace vergonhoso para o exército. Tanto este como o inimigo tendem a uma visão teatral dos acontecimentos, como se pode verificar, por exemplo, através do discurso indireto livre do primeiro recontro, ilusoriamente promissor para a tropa:

“Foi uma diversão gloriosa e rápida. O inimigo furtara-se ao recontro. Volvidos minu- tos, a ala tornou à linha da coluna entre aclamações, enquanto o antigo toque de 'trindades' era agora o sinal da vitória, soava em vibrações altíssimas. $\mathrm{O}$ comandante-em-chefe abraçou, num lance de alegria sincera, o oficial feliz que dera aquele repelão valente no antagonista, e considerou auspicioso o encontro. Era quase para lastimar tanto aparelho bélico, tanta gente, tão luxuosa encenação em campanha destinada a liquidar-se com meia dúzia de disparos.” (p. 345)

Mas o desfecho foi uma desilusão:

"[...] toda a população de Canudos contemplava aquela cena dando ao trágico do lance a nota galhofeira e irritante de milhares de assovios estridentes, longos, implacáveis [...]. Mais uma vez o drama temeroso da guerra sertaneja tinha o desenlace de uma pateada lúgubre." (p. 363)

A derrota do exército é uma tragédia à qual, no entanto, os jagunços reagem como se fosse uma farsa. A partida da tropa de Canudos é descrita quase como uma instrução para um camera-man:

“O desfecho foi rápido. A última divisão de artilharia replicou por momentos e depois, por sua vez, abalou vagarosamente, pelo declive do espigão acima, retirando. Era tarde. Adiante até aonde alcançava o olhar, a expedição, esparsa e estendida pelos caminhos, estava, de ponta a ponta flanqueada pelos jagunços [...].” (p. 363)

O ponto de vista fictício desse cameraman não é, como de ordinário, favorável ao exército, mas aos sertanejos, que vêem a tropa fugindo. E, sendo este ato no fundo outro drama, possui, como todo drama completo, um epílogo, que é uma decoração teatral da via de fuga do exército, quase uma via crucis, uma exposição blasfêmica e infernal dos caídos, encenada pelos conselheiristas, um anticemitério, devendo servir de espantalho para futuras expedições que não tardarão a aparecer. Citemos o ponto alto desse preparo teatral: 
“Um pormenor doloroso completou esta encenação cruel: a uma banda avultava, empalado, erguido num galho seco, de angico, o corpo do coronel Tamarindo. Era assombroso [...]. Como um manequim terrivelmente lúgubre, o cadáver desaprumado, braços e pernas pendidos, oscilando à feição do vento no galho flexível e vergado, aparecia nos ermos feito uma visão demoníaca." (p. 368)

Segue o IV ato, decisivo, embora ainda não traga a decisão final, pois termina com um retardamento causado pelo revés ocorrido no grande assalto de 18 de julho, que por sua vez é narrado no quinto subcapítulo, de importância central no livro, sendo o mais longo e o único com título próprio: "O assalto". Também este ato é estruturado como um drama. $\mathrm{Na}$ sua exposição, o próprio exército inicia teatralmente com uma salva o dia 14 de julho, comemorando o feriado mundial. A este seguem-se outros dias de festa, antecipando a comemoração da vitória tida como certa. Assim termina a exposição da página 446: Toda a $1^{\text {a }}$ coluna penetrava, reunida, na arena do combate. Depois de muitos percalços, vai-e-vens, uma peripécia muito especial: novo revés da tropa, mas que não significa uma vitória dos canudenses, pois seu resultado é uma continuação do empate que já durava desde fins de junho e se transforma numa guerra de trincheiras, parecida com a de Verdun, vinte anos mais tarde, com a imobilidade da frente de combate por mais de dois meses. A batalha de 18 de julho, já prenunciada na primeira parte (v. os higrômetros singulares, ou seja, o soldado e o cavalo mumificados, na p. 112), que deveria trazer a decisão final, funciona como o clássico retardamento do drama, aumentando o suspense. Este revés, no mínimo uma semiderrota, é apresentado pelo comandante-em-chefe como vitória diante dos olhos da nação, sendo esta aparência desfeita, porém, pela ironia sarcástica do autor.
O V ato - "Nova fase da luta" e "Últimos dias" - apresenta ação menos heróica e mais metódica do exército, sendo os verdadeiros heróis, no caso, os comboios de burros comandados pelo ministro. Os sertanejos têm aí atuação mais lancinante e heróica e o desenlace definitivo está repleto de avanços, recuos e retardamentos, que aumentam o suspense. Afinal, a relação entre vaiadores e vaiados é invertida por meio de uma cena (p. 505) onde caem as torres da igreja nova, símbolos e ao mesmo tempo baluartes reais da combatividade e da resistência dos sertanejos.

\section{A batalha como ficção real e a ambigüidade do espectador-narrador}

A cena mais espetacular, porém, chamada pelo próprio autor de ato de uma tragédia e narrada sistematicamente em metáforas teatrais que se vão tornando denominações próprias é o complemento do assédio no dia 23 ou 24 de setembro de 1897 (p. 524, especialmente a partir da linha 142, até a p. 526, linha 202). Esta cena é vista como espetáculo não só pelo autor como também pelos próprios protagonistas, ou seja, pelo exército, configurando, portanto, um drama não apenas metafórico, mas real. É o ponto onde a tendência da própria história se apresentar como peça de teatro mostra-se mais evidente. A cena correspondente, ou seja, a batalha que resulta no fechamento do sítio de Canudos, tem início na página 523 , linha 82 ; mas até a linha 141 da p. 524 ela é narrada epicamente, de modo plástico e ilustrativo, é verdade, mas ainda não exatamente como uma peça de teatro, como ato de tragédia (p. 525, linha 154). A partir da linha 142,5 porém, o narrador enfoca também a parcela temporariamente ociosa do exército que está observando o combate como se estivesse no teatro, a partir do acampamento nos morros circundantes. A narração é feita parcialmente do

5 Desde Fernando Nery, organizador da edição de 1933 da Editora Francisco Alves, alguns editores deram a esse trecho o entretítulo de "Cenário da tragédia", pois na verdade ele é apresentado como um 
ponto de vista desses espectadores, criticando-o implicitamente. Segue então uma espécie de epílogo, que resume em linguagem referencial os resultados da refrega, detalhes do fechamento do cerco, e culmina no balanço final: " $A$ insurreição estava morta” - a última e dramática frase do penúltimo capítulo de Os Sertôes.

Trata-se de um combate vivenciado não só pelo narrador, mas também pelo próprio autor, que àquela data estava em Canudos. Neste trecho o narrador não identifica sua presença no campo de batalha, não aparecendo na primeira pessoa do singular ou do plural, como é o caso noutras vezes, embora raras. Mas ele não é o único espectador. Este combate se presta perfeitamente a ser descrito e narrado como uma cena de teatro, porque há espectadores de verdade. Um dos partidos beligerantes se divide em dois grupos: um que age, que luta e outro que observa, se diverte e torce pela vitória dos companheiros, desejando a derrota dos inimigos. Aquele que se pode dar ao luxo de transformar a batalha em espetáculo e a si mesmo em espectador pertence, naturalmente, ao partido que está com a vantagem militar. Diante da vitória iminente, a guerra se apresenta aos soldados sob um aspecto lúdico, de modo que metade do exército pode-se transformar em público, considerando a guerra quase um divertimento, um jogo esportivo, um passatempo. Em princípio, o grosso do trabalho está feito e a guerra, decidida, embora não ainda no plano prático.

Nesta cena, podemos observar mais uma vez a imbricação entre os aspectos pictóricos e dramatúrgicos. Há uma sucessão rápida e dramática de eventos que são sustidos, contidos ou paralisados, para poderem ser descritos como quadros. Esta tendência descritiva na narração de uma seqüência de fatos manifesta-se no uso sistemático do imperfeito como tempo grama- tical do passado, em vez do pretérito perfeito, como seria de se esperar num relato sobre um drama. Além do imperfeito expressar a repetitividade e a rotina de muitas situaçôes de combate, ele também desacelera a velocidade dos eventos, permitindo um olhar contemplativo, preocupado com detalhes, paciente e exato da realidade, além de manifestar certa subjetividade, o gesto explicativo, dêitico, convidando o leitor a acompanhar pormenorizadamente os acontecimentos. Por vezes o uso do imperfeito parece até estranho, um oximoro sintático, por assim dizer, como por exemplo no seguinte trecho:

"Diante dos espectadores estendia-se, lisa e pardacenta, a imprimadura, sem relevos, do fumo. Recortava-a, rubro e sem brilhos, uma chapa circular em brasa - um Sol bruxuleante, de eclipse. Rompia-a, porém, de súbito, uma lufada rija."

“Rompia-a, porém, de súbito..." é uma combinação estranha de um advérbio expressando rapidez e surpresa e um tempo gramatical que enfatiza o caráter lento, estagnado ou processual de uma situação, criando assim a ilusão da simultaneidade entre o desenrolar da cena e sua observação pelo espectador-narrador. Estranha igualmente é a expressão lufada rija, um verdadeiro oximoro, já que lufada expressa um processo dinâmico, ao passo que rijo caracteriza situação estática, fixa, estagnada. Também se poderia dizer que lufada representa o elemento dramático, e rija, o elemento pictorial.

Esta cena é um resumo de toda a guerra: de um lado os sertanejos encurralados, acuados, bombardeados pela artilharia dos soldadosespectatores e combatidos pela infantaria do lado oposto, derrotados quase, morrendo, mas lutando sozinhos como leões contra o agressor, que tem como aliados o país todo e o resto do

ato de tragédia. A introdução de entretítulos por parte de alguns editores e tradutores, valendo-se dos itens nos sumários de cada uma das oito partes do livro e de palavras-chaves dentro do próprio texto tradição naturalmente seguida por Afrânio Coutinho na edição da Aguilar, e, até certo ponto, também por mim, na tradução alemã - reforça a teatralidade inerente do livro. Ver Walnice Nogueira Galvão, "Introdução". In: Cunha, 1985, p. 23. 
mundo. E o tiro de misericórdia não tardará a chegar. Esta vitória parcial é a condição decisiva e o prenúncio da vitória definitiva do exército. A partir da linha 142 da página 524, o ponto de vista do narrador é o dos soldados-espectadores, embora não haja aí uma identificação emocional com estes. Pois os não-combatentes entre os soldados se comportam como espectadores de uma peça sobre um conflito entre dois grupos inimigos, como se aquilo fosse um combate de teatro, fictício, uma farsa ou um dramalhão, uma luta de boxe, com mocinhos e vilóes, entre os quais as simpatias fossem claramente repartidas. Só que no teatro ou no esporte ninguém morre de verdade. A cena real se apresenta aos olhos dos soldados não-combatentes com uma ficção estupenda. E no fim do combate, no fechamento do cerco a Canudos, que sela sua derrota, os próprios soldados no palco também se comportam como espectadores, aclamandose a si mesmos: "Ouvia-se, porém, longínquo, um ressoar de brados e vivas, aplauso que logo depois se funde com o dos companheiros nos camarotes." (p. 526)

Essas exclamações, não citadas literalmente, são as únicas palavras, rudimentares, que se podem ouvir. Pois esse espetáculo que se desenrola sob os olhos do comandante-em-chefe, dos oficiais e soldados que não combatem naquela hora, do narrador sincero Euclides da Cunha e do leitor é um espetáculo mudo. Não se ouvem diálogos, como normalmente os há no teatro, porque realmente nunca houve diálogo, comunicação ou negociação entre o exército e a comunidade de Canudos, e sim vaias e palavróes; mas também não se ouvem as palavras trocadas dentro de cada partido beligerante, por causa da distância, o que dá prioridade à percepção visual da cena, muda, exceto pelo ruído de canhōes e fuzis que substituem as palavras. A ausência das vozes humanas facilita também a estetização do combate, pois não se ouvem gritos de dor ou de luto.

Poder-se-ia especular sobre a função das palavras do próprio narrador, que se mostra muito eloqüente diante dessa tragédia silenciosa, mas só posteriormente, enquanto cronista-espectador, não como personagem-espectador $\mathrm{da}$ cena, pois como tal permanece mudo. $\mathrm{O}$ autor, como testemunha, deve ter encarado os acontecimentos sub specie aeternitatis, ou pelo menos sub specie historiae, não como agente, participante ativo. Observava tudo com a futura narrativa na mente. Parece-me que tanto no trecho em questão, como em todo o livro, de modo geral, o narrador retoma e amplia o papel do coro da tragédia clássica, comentando os acontecimentos, lamentando as vítimas, acusando os vencedores, sensibilizando os espectadoresleitores, invocando os valores da Nação e da Civilização, clamando pelo Destino, dirigindo-se à posteridade, apelando para o juízo da História.

Implicitamente, pelo menos, o narrador reprova as manifestações de triunfo. É evidente a falta de competência ética e estética dos soldados-espectadores, que cometem dois erros: comportam-se diante desse combate real como se fosse uma peça de teatro e se comportam nesse teatro como se fosse uma farsa ou um dramalhão, de qualquer forma um espetáculo de entretenimento. O narrador e com ele os letrados do Brasil e do mundo inteiro também assumem a perspectiva de espectadores, são vizinhos e cúmplices dos soldados, esperando e desejando com eles a vitória do exército, mas distanciando-se deles ao mesmo tempo. De modo que os leitores, assim como o narrador, ficam dilacerados entre duas perspectivas e atitudes: a dos espectadores-soldados e a de espectadores destes soldados-espectadores. Pois estes representam um espetáculo dentro do espetáculo, desempenhando o papel escandaloso de público indigno, mal-educado e bárbaro. Euclides cria, portanto, uma espécie de metateatro, encenando criticamente a batalha teatralizada pelos soldados-espectadores. Ele nos faz sentir o mesmo constrangimento que nos acometeria se, na peripécia de um drama de Sófocles, um espectador ao nosso lado começasse a falar alto, a apoiar um dos partidos conflitantes, vaiando, dando gargalhadas, batendo palmas. O que irrita tanto ao narrador como a nós é que 
seus co-espectadores não sentem, não avaliam, não entendem o que acontece lá no palco. $\mathrm{O}$ que se desenrola diante de seus olhos e dos nossos, nas ruínas fumegantes de Canudos, é um fato real, uma tragédia, como já apontamos, em que não há necessariamente personagens bons e maus, amigos e inimigos claramente distribuídos, como ocorre em geral numa comédia, num jogo, numa luta de gladiadores, numa ficção. A reação desses espectadores incultos e insensíveis, porém, não está à altura nem do gênero nem do tema, pois eles não têm consciência do trágico, como o autor, nem se dão conta de que no palco da guerra se está destruindo o cerne de uma nacionalidade, a rocha viva da nossa raça (p. 559). Eles não se emocionam com a desgraça dos vencidos, com a derrota de uma comunidade heróica, com o fim de um projeto social fascinante, ao mesmo tempo condenado e admirado, um pouco às escondidas, pelo próprio Euclides, e, graças à sua força de persuasão, também por nós, seus leitores.

O distanciamento implícito do narrador em relação aos soldados-espectadores, que revela sensibilidade estética e até alguma compaixão para com os perdedores, não deixa de ser problemático por outro lado. O narrador invisível, e com ele nós, seus leitores, somos induzidos a ver o ocaso de Canudos com um olhar teatral e a criticar-nos ao mesmo tempo, justamente porque, além do horror e do luto, sentimos também prazer estético, mais refinadamente que os soldados, certo, um prazer mesclado de consciência de culpa. Nem por isso, entretanto, o narrador-espectador intervém junto a seus companheiros militares, não solta nenhum grito de protesto, não roga para que sejam poupadas pelo menos mulheres e crianças. Afinal, ele pertence, como nós, ao mesmo partido beligerante. Essa vacilação entre a perspectiva dos espectadores-soldados e a rejeição indignada desta mesma perspectiva, a camaradagem do narrador para com os militares e sua condenação implícita expressa a ambigüidade dos intelectuais progressistas, que muitas vezes defendem o povo emocional e verbalmente e se aliam na prática às classes dirigentes, seja por ideologia, por necessidade profissional ou por ambição. $\mathrm{O}$ narrador não se distancia dos soldados enquanto combatentes: estes têm que lutar, que matar, que vencer, o que não lhes dá o direito de vaiar, patear, dar brados e vivas. ${ }^{6}$ No entanto, depois da luta, teriam que se vestir de luto como o próprio narrador, como o autor, como nós, leitores. Se a matança tem que acontecer, que seja praticada com sentimento de culpa, esta, sim, seria uma atitude digna diante de uma realidade que por si só é uma tragédia e que só como tal poderia ser representada. Se a Nação teve que cometer um crime, que pelo menos se redima através do respeito pelos caídos.

A percepção da guerra como teatro, tradicional recurso literário, também se encontra, ainda que em grau menor e mais incipiente, nos outros escritos da época sobre Canudos. Ela é fomentada pelo uso de armas de longa distância e especialmente pela artilharia, que no caso está ao lado dos espectadores, do narrador e de certa forma também do leitor. A perspectiva do narrador é muito semelhante à do soldado artilheiro, que, embora combatente, pode contemplar com certa serenidade e isenção o teatro da guerra, metáfora internacional freqüente na época, já que as conseqüências de sua ação militar não o afetam diretamente, sobretudo quando dispõe da superioridade total do armamento. É este o caso do exército em Canudos: só um dos partidos beligerantes dispõe de canhões, através do quais, a partir dos camarotes dos espectadores, envia a morte ao palco da batalha, sem que as vítimas possam replicar. Foi também a superioridade das armas de longa distância que permitiu aos americanos transformar a Guerra do Golfo em espetáculo.

6 Manifestações de escárnio e triunfo sobre os canudenses já foram censuradas anteriormente pelo narrador (p. 505 e 506, por exemplo). 
Há outro motivo para essa teatralização, que aproxima o escritor-historiador do estrategista: ambos precisam de uma visão de conjunto da multiplicidade aparentemente caótica dos acontecimentos simultâneos e sucessivos, a fim de poder organizá-los e ordená-los mentalmente no espaço e no tempo: o militar, para dirigilos, o autor, para narrá-los. Isto vale de modo especial para Euclides da Cunha, tenente reformado e companheiro de muitos oficiais em $\mathrm{Ca}$ nudos desde a Escola Militar, que em muitos trechos de seu livro não pode se abster de dar palpites aos comandantes das expedições. Em Os Sertôes há vários enfoques na narração de combates: há o olhar de baixo, do participante envolvido no caos, não entendendo nada do que está acontecendo, visão esta cuja versão extremada seria a que Fabrice del Dongo expóe da batalha de Waterloo em La Chartreuse de Parme, de Stendhal; mas há também a visão aquilina do perito militar, para o qual a teatralização é um instrumento de organização dos acontecimentos confusos e opacos. E justamente a batalha de 23/24 de setembro é narrada em três trechos, cada vez de uma maneira diferente:

a) numa perspectiva de dentro do campo de batalha, com enfoques tanto a partir do ponto de vista dos sertanejos como daquele dos soldados - enfim, a partir de Canudos; aí há pouca visão do conjunto, embora o narrador seja onisciente, ficcional, pois é claro que o autor não entrou no arraial naquele dia (p. 523, linha 82, até p. 524, linha 141);

b) como espetáculo visto a partir de um ponto de vista fixo, ou seja, de cima, do quar- tel-general, que ficava a leste de Canudos, com o bairro Casas Vermelhas tomado naquele dia pela tropa, ao norte, e os canhóes do Morro da Favela ao sul, sendo os últimos defensores de Canudos abatidos a meio caminho; tal encenação, proporcionada pela própria realidade, dava uma perfeita visão estratégica e de conjunto da guerra, incluindo a reação dos soldados não combatentes; há aí relativamente pouca ficcionalização, pois o narrador, sem ser onisciente, só conta o que o autor realmente poderia ter visto (p. 524, linha 142, até p. 526, linha 202, com epílogo até linha 218);

c) como visão de conjunto, mas focalizando apenas a ação coletiva dos defensores de Canudos, representada como espécie de corrente de águas ou maré, sem metáforas teatrais, sem abranger o exército e a sua visão da batalha (p. 529, linha 1 , até p. 531, linha 89). ${ }^{7}$

Se a continuação da batalha do dia 23 de setembro, depois do fechamento do cerco, não aparece mais em forma teatral, é também porque os soldados-espectadores de repente se vêem forçados, pela combatividade ressurrecta dos canudenses, a abandonar a platéia e os camarotes. Os espectadores têm que se transformar em combatentes, substituindo o olhar curioso pela ansiosa preocupação de se proteger das balas daqueles que já pareciam vencidos, mas que resistiram tão ferozmente que o seu paroxismo estupendo acovardava os vitoriosos.

O destino dos canudenses está, porém, selado, é só um estrebuchar dos vencidos. No final, ocorre até uma espécie de ressurreição simbólica e caricaturesca do messias do sertão, empreendida pelo exército: "Desenterraram-no

7 Sobre essa batalha, o autor indica ora uma, ora outra data (p. 523, linha 81 ou p. 529, linha 12). Provavelmente a imaginação rememorativa do autor fundiu os combates dos dois dias num só. É que o fechamento do cerco aconteceu mesmo no dia 23, mas relativamente longe do miradouro do narrador, situado perto do quartel general, a leste do arraial, ao passo que os combates observáveis a partir daquele lugar, a constrição do cerco, trazendo os combates para dentro de Canudos, aconteceram no dia 24. A oscilação entre as duas datas traduz a ambigüidade de Euclides entre duas posturas: a do cronista objetivo, que não pode negar que o sítio de Canudos se completou em 23 de setembro, e a do narrador presentificador e encenador da história, que prefere nos apresentar uma cena mais densa, mais plástica e apta para ser teatralizada. 
cuidadosamente. [...] e a face horrenda, empastada de escaras e de sânie, apareceu ainda uma vez ante aqueles triunfadores" (p. 572). A saída do túmulo que o exército proporciona ao Bom Jesus de Canudos é uma profanação, um sacrilégio, uma paródia de ressurreição. $\mathrm{O}$ Anticristo, na visão dos Canudenses, e quem sabe também na de Euclides, se arroga funções divinas, desenterrando o Conselheiro, não para provar que ele está vivo, mas para provar que está morto. E a epifania acontece como duplo escárnio por meio da cabeça decepada e ostentada, mas também através da fotografia, ambas usadas como meios de identificação e análise e também como pontos altos de uma mostra sensacionalista sobre a guerra nas grandes cidades.

Os dois objetos têm, porém, destino não calculado pelo exército, testemunhando contra ele próprio. Levar a cabeça do Conselheiro para a grande cidade a fim de mostrá-la em público, como dá a entender Euclides, e ao mesmo tempo para submetê-la a exame científico é uma encenação macabra e indigna da missão civilizadora reclamada pelos militares, pondo-os no mesmo nível bárbaro dos canudenses. Estes, depois de sua vitória sobre a terceira expedição, a de Moreira César, tinham, numa encenação cruel, alinhado as cabeças nas duas bordas da estrada, regularmente espaçadas, fronteando-se, faces volvidas para o caminho, assim como erguido num galho seco, de angico, o corpo do coronel Tamarindo, feito uma visão demoníaca. Assim, o exército tenta apresentar o Conselheiro também como visão demoníaca, além de troféu de guerra e prova de morte do "famigerado e bárbaro" agitador. Anos mais tarde, seu crânio foi destruído num incêndio ocorrido na Faculdade de Medicina de Salvador. A fotografia, porém, sobreviveu, virando a peça mais conhecida e divulgada do álbum do fotógrafo Flávio de Barros. (ver Almeida, 1997, p. 80-1) E paradoxalmente, numa curiosa analogia com outro libertador malogrado das massas camponesas na América Latina, o "Che", a fotografia desse mártir, embora tirada por seus assassinos, assemelhando-se a representações populares de Cristo, propagou a imagem do Conselheiro como ícone das esperanças de salvação e renovação, dentro e fora do âmbito religioso, contribuindo para sua imortalidade. Basta pensar no movimento dos sem-terra, que considera o fundador de Canudos como um dos precursores da organização do povo do campo na luta por sua libertação. No caso do líder sertanejo, a fotografia é o único retrato autêntico que existe, de modo que um personagem importante da história brasileira sobrevive em termos imagéticos apenas como morto, ainda que extremamente ativo e influente. É com o desfile do crânio ante os atores e leitores, espetáculo bárbaro de triunfo guerreiro e ao mesmo tempo ritual de pesquisa científica, que tanto o exército como Euclides concluem suas encenações da guerra de Canudos, sendo que a encenação do escritor engloba criticamente a de seus colegas militares.

Com sua força imagética e teatralizadora, a história literarizada transforma o passado em história, esconjurando o esquecimento, transfigurando e eternizando eventos e personagens. Graças, em grande parte, ao livro de Euclides da Cunha, esse demiurgo da memória, o Conselheiro e seu povo tiveram imediata ressurreição, bem como repetidas epifanias, que foram mais uma vez confirmadas no centenário de Canudos, em 1997. Com cada nova releitura de Os Sertôes, ficamos novamente comovidos, escandalizados e entristecidos, ao ter evocados diante de nossos olhos e ouvidos, através da magia verbal presentificadora do escritor-orador-encenador Euclides da Cunha, os painéis e as cenas daquele fascinante projeto social e de seu trágico malogro. 


\section{Referências bibliográficas}

ALMEIDA, Cícero Antônio F. Canudos Imagens da guerra: Os últimos dias da guerra de Canudos pelo fotógrafo expedicionário Flávio de Barros. Rio de Janeiro: Museu da Republica / Lacerda Editores, 1997.

BERNUCCI, Leopoldo. A imitação dos sentidos: Prógonos, contemporâneos e epígonos de Euclides da Cunha. São Paulo: Edusp, 1995.

COUTINHO, Afrânio. Os Sertôes, obra de ficção. In: CUNHA, Euclides da. Obra completa. Rio de Janeiro: Aguilar, 1966, v. II, p. 57-62. (2ae ed. 1995)

CUNHA, Euclides da. Os Sertôes. Edição crítica de Walnice Nogueira Galvão. São Paulo: Brasiliense, 1985.

Obra completa. Edição organizada por Afrânio Coutinho. Rio de Janeiro: Aguilar, 1966, 2 v. (2 ed., 1995).

GALVÃO, Nogueira Walnice; GALOTTI, Oswaldo. Correspondência de Euclides da Cunha. São Paulo: Edusp. 1997.

JOLLES, André, Formas simples: legenda, saga, mito, ditado, caso, memorável, conto, chiste. Trad. de Álvaro Cabral. São Paulo: Cultrix. 1976. 